\title{
Kebijakan Pembinaan Pejabat Fungsional Dokter Aparatur Sipil Negara Terhadap Pelanggaran Kode Etik Dokter
}

\section{Policy on the Development of Doctor's Functional Officials in the State Civil Apparatus Against Violation of the Doctor's Code of Ethics}

\author{
Apriyanto \\ apriy.73@gmail.com
}

Dinas Kesehatan Lampung Utara

Submitted: Mar 16, 2020; Reviewed: Apr 13, 2020; Accepted: Mei 4, 2020

\begin{tabular}{|c|c|}
\hline Info Artikel & Abstrak \\
\hline $\begin{array}{l}\text { Kata Kunci: Pelanggaran Etik; } \\
\text { Wewenang; ASN. } \\
\text { Keywords: Ethics; Authority; ASN } \\
\text { Violation. }\end{array}$ & $\begin{array}{l}\text { Seorang dokter Aparatur Sipil Negara (ASN) } \\
\text { dalam penyelenggaraan praktik kedokteran } \\
\text { berpotensi dikenai sanksi etik oleh organisasi } \\
\text { profesinya berupa rekomendasi pencabutan } \\
\text { Surat Izin Praktik yang menyebabkan hilangnya }\end{array}$ \\
\hline $\begin{array}{l}\text { DOI: } \\
\text { https://doi.org/10.25041/aelr.v1i1.2080 }\end{array}$ & $\begin{array}{l}\text { wewenang berpraktik. Berdasarkan hal tersebut, } \\
\text { kehilangan kewenangan setidaknya akan } \\
\text { menimbulkan pertanyaan apakah kehilangan } \\
\text { wewenang menjalankan profesi dokter akan } \\
\text { berimplikasi terhadap jabatan fungsionalnya } \\
\text { sebagai dokter ASN dan bagaimanakah } \\
\text { kebijakan pembinaan sebagai pejabat fungsional } \\
\text { dokter ASN dalam hubungannya dengan } \\
\text { pelanggaran etik dokter. Penelitian dilakukan } \\
\text { dengan pendekatan pendekatan undang-undang } \\
\text { (statue approach) dan pendekatan kasus (case } \\
\text { approach). Hasil penelitian adalah kehilangan } \\
\text { wewenang formil akibat pelanggaran etik tidak } \\
\text { berimplikasi terhadap jabatan fungsional dokter } \\
\text { dan pembinaan yang dilakukan pada dokter } \\
\text { ASN yang mendapat sanksi pelanggaran etik } \\
\text { berupa uji kompetensi ulang, mutasi, dan } \\
\text { pemberhentian. Saran diperlukan peraturan }\end{array}$ \\
\hline
\end{tabular}


perundang-undangan yang menjelaskan makna stipulatif tentang hubungan pelanggaran etik dengan penerapan sanksi disiplin sehingga memudahkan dalam melakukan pembinaan dokter ASN yang terkena sanksi pelanggaran Kode Etik.

Abstract
A doctor of the State Civil Apparatus (ASN) in
the implementation of medical practice has the
potential to be subject to ethical sanctions by his
professional organization in the form of a
recommendation to revoke the Practice License
which causes loss of authority to practice.
Based on this, the loss of authority will at least
raise the question of whether losing the
authority to carry out the medical profession
will have implications for his functional position
as an ASN doctor and what is the coaching
policy as an ASN doctor functional official in
relation to violations of doctor ethics. The
research was conducted with a statue approach
and a case approach. The result of the research
is that the loss of formal authority due to ethical
violations does not have implications for the
functional position of doctors and the guidance
carried out by ASN doctors who have been
sanctioned for ethical violations in the form of
re-competency tests, transfers, and dismissals.
Suggestions are needed by laws and regulations
that explain the stipulative meaning of the
relationship between ethical violations and the
application of disciplinary sanctions to make it
easier for ASN doctors who are sanctioned by
violations of the Code of Ethics.

\section{A. Pendahuluan}

Seorang Dokter Aparatur Sipil Negara (ASN) dalam penyelenggaraan praktik kedokteran terikat dengan kode etik kedokteran dapat dikenakan sanksi oleh organisasi profesinya berupa rekomendasi pencabutan Surat Izin Praktik (SIP) ${ }^{1}$ yang menyebabkan hilangnya wewenang berpraktik. Sanksi pencabutan baik berupa pencabutan Surat Tanda Registrasi (STR) ataupun SIP akan berimbas bukan semata-mata hanya kepada dokter yang terkena sanksi, namun berakibat pula terhadap manajemen kepegawaian dilembaga pelayanan kesehatan tempat dokter tersebut bekerja. ${ }^{2}$ Dokter ASN yang mendapat sanksi pencabutan SIP, tidak

\footnotetext{
${ }^{1}$ Irfan, Januarita Dyah Pitaloka, Adif Rachmat Nugraha, "Rekrutmen ASN Tenaga Kesehatan Untuk Merespon Covid-19", The Indonesian Journal of Development Planning, Vol 4 No.2, (2020), hlm 218-219.

${ }^{2}$ Fred Amein, dikutip Yussy A. Mannas, "Hubungan Hukum Dokter dan Pasien Serta Tanggung Jawab Dokter Dalam Penyelenggaraan Pelayanan Kesehatan”, Jurnal Cita Hukum, Vol 6 No.1, (2018), hlm. 176-177.
} 
diperkenankan melakukan praktik kedokteran sesuai peraturan perundang-undangan. Tidak diperkenankan melakukan tindakan profesionalnya berakibat dokter ASN tersebut tidak dapat memenuhi kewajibannya sebagai pejabat fungsional ASN dalam jabatan fungsional dokter. ${ }^{3}$

Permasalahan tersebut mendorong penulis melakukan penelitian terhadap hak menjalankan profesi, apakah dokter ASN yang kehilangan wewenang menjalankan profesi dokter akan berimplikasi terhadap jabatan fungsionalnya sebagai dokter ASN? dan bagaimanakah kebijakan pembinaan sebagai pejabat fungsional dokter ASN dalam hubungannya dengan pelanggaran etik dokter. Dari hasil penelitian yang dilakukan diperoleh pandangan dan rekomendasi bagi pemangku kepentingan dalam pengelolaan manajeman ASN terhadap bagi ASN dokter khususnya dan profesi dengan jabatan fungsional tertentu lainnya yang mendapat sanksi pelanggaran etik. Penelitian hukum dengan karakteristik normatif dilakukan dengan menggunakan pendekatan kasus/case approach berupa sanksi pelanggaran etik bagi dokter ASN dan pendekatan peraturan perundang-undangan/statue approach yang berhubungan dengan permasalahan tersebut.

\section{B. Pembahasan}

\section{Kehilangan Wewenang Dalam Menjalankan Profesi Dokter Dan Implikasinya Terhadap Jabatan Fungsional Dokter ASN}

Wewenang (competence, bevoegdheid) ${ }^{4}$ adalah kemampuan untuk melakukan suatu tindakan hukum publik berupa kemampuan untuk melakukan hubungan hukum yang diberikan undang-undang. ${ }^{5}$ Wewenang didasarkan atas asas demokrasi dan asas legalitas dalam negara hukum dan demokrasi. Asas legalitas dapat terjadi karena dua hal yakni diberikan oleh badan legislatif kepada administrasi negara melalui atribusi atau diberikan dari administrasi negara kepada administrasi negara lain melalui perundangan-undangan dengan cara derivatif. ${ }^{6}$ Pelimpahan Derivatif didasarkan adanya wewenang atributif, pelimpahannya dilakukan dengan cara delegasi atau mandat. Delegasi adalah pelimpahan wewenang oleh suatu organ pemerintahan kepada pihak lain dibawahnya untuk mengambil keputusan dengan peralihan tanggung jawab dan tanggung gugat kepada penerima delegasi.

Profesi dokter adalah profesi yang memenuhi kebutuhan pangkat dan jabatan ASN. Salah satu ciri-ciri khusus profesi yakni suatu sistem okupasional menurut Parson ${ }^{7}$ adalah "spesifisitas fungsional", dengan ciri khas memiliki otoritas yang bertumpu pada kompetensi teknikal tertentu yang selalu terbatas pada satu bidang pengetahuan dan keahlian tertentu. Menurut Arief B. Sidharta, ${ }^{8}$ Suatu profesi merupakan kerangka institusional yang menjalankan fungsi kemasyarakatan yang paling mendasar yang mencakup:

1) Pengembangan dan pengajaran ilmu dan humaniora; dan

2) Penerapannya dalam bidang-bidang pelayanan rohani, kedokteran, teknologi, hukum, informasi dan pendidikan.

Dokter juga memiliki keterikatan dalam menjalankan tugasnya kepada seorang pasien. Hubungan tersebut dinamakan hubungan Terapeutik yakni suatu hubungan yang di dasari sifat kepercayaan seorang pasien kepada dokter. Artinya, hubungan tersebut melahirkan suatu

\footnotetext{
${ }^{3}$ Nelson Bastian Nope, "Mutasi Pejabat Fungsional ke Dalam Jabatan Struktural Di Era Otonomi Daerah”, Jurnal Yusticia, Vol 4 No.2, (2015), hlm 352.

${ }^{4}$ Lukman Hakim, "Kewenagan Organ Negara Dalam Penyelenggaraan Pemerintahan”, Jurnal Konstitusi, Vol 4 No.1, (2011), hlm 117-118.

${ }^{5}$ Marbun, S.F., Hukum Administrasi Negara I (Administrative Law I), Yogyakarta, FH UII, Cetakan Kedua, 2018, hlm. 117

6 Suwardi Sagama, "Reformulasi Hierarki Peraturan Pada Pembentukan Peraturan Perundang-Undangan di Indonesia", Jurnal Volksgeist, Vol 2 No. 2, (2018), hlm 188.

${ }^{7}$ Arief B. Sidharta, “Etika dan Kode Etik Profesi Hukum”, Veritas et Justitia, Vol 1 No.1, (2015), hlm 225-226.

${ }^{8}$ Ibid, hlm. 220.
} 
perikatan moral, apabila hubungan tersebut dilaksanakan secara tertulis maka memiliki akibat hukum dikarenakan seorang pasien memberikan prestasinya kepada dokter sedangkan dokter berkewajiban memberikan kontra prestasi kepada pasien. ${ }^{9}$ Apabila terdapat wanprestasi dalam hubungan tersebut maka acapkali seorang pasien memilih penyelesaian sengketa melalui pengadilan dengan gugatan mall praktik seorang dokter terhadap pasien. ${ }^{10}$ Di lain hal, profesi dokter disebut sebagai suatu profesi karena melakukan suatu pekerjaan yang bersifat memberikan pelayanan dengan dua unsur yakni:

a. Menerapkan seperangkat pengetahuan yang tersusun secara sistematis terhadap problema-problema tertentu; dan

b. Problema-problema tersebut mempunyai relevansi yang besar dalam hubungannya dengan nilai-nilai yang dipandang pokok dalam masyarakat. ${ }^{11}$

Pasal 1 angka 11 Undang-Undang No. 29 Tahun 2004 Tentang Praktik Kedokteran menyatakan profesi kedokteran adalah suatu pekerjaan kedokteran yang dilaksanakan atas dasar keilmuan, kompetensi yang didapat melalui pendidikan yang berjenjang, dan kode etik yang menjadi dasar pemberian pelayanan kepada masyarakat, menunjukkan wewenang seorang dokter merupakan kewenangan hukum (rechtbevoegheid) dalam negara demokrasi yang dimiliki berupa hak untuk bekerja sesuai dengan disiplin keilmuannya. Hak seorang dokter menurut sifatnya terdiri atas wewenang yang berdasarkan keahlian yang dimiliki dokter disebut sebagai kewenangan materiil/materiel dibuktikan dengan STR ${ }^{12}$ dan wewenang yang didasarkan atas ketentuan peraturan perundang-undangan atau disebut sebagai kewenangan formil/formiel yang dibuktikan dengan SIP. ${ }^{13}$ Dalam menjalankan hak praktiknya, setiap dokter terikat dengan kode etik profesi sebagai mekanisme kontrol pada perilakunya. Pelanggaran etika kedokteran akan ditangani dan disidangkan oleh Majelis Kehormatan Etik Kedokteran (MKEK) sebagai organ otonom dari Ikatan Dokter Indonesia (IDI), untuk dimintai pertanggung-jawaban etik profesi dokternya. ${ }^{14}$ Tujuan dari persidangan MKEK adalah mempertahankan akuntabilitas, profesionalisme dan keluhuran profesi. Persidangan MKEK bersifat inkuisitorial khas profesi. Maksud inkuisitorial disini adalah Majelis (ketua dan anggota) bersikap aktif melakukan pemeriksaan, tanpa adanya badan hukum atau orang sebagai penuntut. ${ }^{15}$ Putusan MKEK pada derajat pelanggaran yang serius dapat dikenai sanksi skorsing hingga rekomendasi pencabutan izin praktik.

Rekomendasi pencabutan izin praktik dieksekusi oleh Kepala Dinas kesehatan Kabupaten Kota dengan mencabut SIP berpegang dengan asas contrarius actus. ${ }^{16}$ Philipus M. Hadjon menyatakan bahwa asas contrarius actus dalam hukum administrasi negara adalah asas yang menyatakan badan atau pejabat tata usaha negara yang menerbitkan keputusan tata usaha negara dengan sendirinya juga berwenang untuk membatalkannya. ${ }^{17}$ Dengan demikian dokter yang bersangkutan kehilangan wewenang formilnya. Kehilangan wewenang ini tidak lantas

\footnotetext{
${ }^{9}$ Dian Mauli, “Tanggung Jawab Hukum Dokter Terhadap Kesalahan Diagnosis Penyakit Kepada Pasien”, Jurnal Cepalo, Vol 2 No.1, (2018), hlm 34.

${ }^{10}$ Setyo Trisnadi, "Perlindungan Hukum Profesi Dokter Dalam Penyelesaian Sengketa Medis", Jurnal Pembaharuan Hukum, Vol 4 No. 1, (2017), hlm 26.

11 Idris, Mas'ud, Tanggung Jawab Dan Etika profesi Dokter Dalam Bidang Hukum, https://media.neliti.com/media/publications/12557-ID-tanggung-jawab-dan-etika-profesi-dokter-dalam-bidang-hukum.pdf, diakses tanggal 27 desember 2019, hlm 102-103.

${ }^{12}$ Pasal 29 ayat (3) UU Praktik Kedokteran

${ }^{13}$ Pasal 35 ayat (1) UU Praktik Kedokteran

${ }^{14}$ Julius Pelafu, "Pelaksanaan Penegakan Kode Etik Kedokteran”, Jurnal Lex Crimen, Vol 4 No. 3, (2015), hlm 47-48.

${ }^{15}$ Sukohar Asep, Novita Carolia, "Peran Majelis Kehormatan Etik Kedokteran Indonesia (MKEK) dalam Pencegahan dan Penyelesaian Malpraktek Kedokteran", Jurnal Kedokteran Unila Vol (1) Nomor 2, (2016), hlm. 365.

16 Sidik Kahono, Muhammad Junaidi, A. Heru Nuswanto, "Tinjuan Yuridis Terhadap Ketentuan Asas Contrarius Actus Menurut Undang-Undang Nomor 16 Tahun 2017 tentang Penetapan Peraturan Pemerintah Pengganti Undang-Undang Nomor 2 Tahun 2017 tentang Perubahan Atas Undang-Undang Nomor 17 Tahun 2013 tentang Organisasi Kemasyakaratan, Jurnal Semarang Law Review, (2020), hlm 95.

${ }^{17}$ Majalah Mahkamah Konstitusi, diakses pada selasa, 6 Januari 2019, pukul 10.37 WIB.
} 
menyebabkan dokter yang bersangkutan kehilangan kompetensinya berupa pengakuan sebagai dokter (wewenang materiel). ${ }^{18}$ Ini bermakna yang bersangkutan masih seorang dokter tapi tidak dapat berpraktik. Dasar manajemen jabatan ASN dalam menimbang adalah perbandingan kualifikasi dan kompetensi jabatan yang dibutuhkan dengan kualifikasi dan kompetensi calon. ${ }^{19}$ Dari sini dapat diambil kesimpulan Jabatan fungsional sebagai dokter tidak hilang tapi wewenangnya menjadi cacat/tidak lengkap.

\section{Kebijakan Pembinaan Pejabat Fungsional Dokter Asn Dalam Hubungannya Dengan Pelanggaraan Kode Etik Dokter}

Fatwa (MKEK PB IDI) Nomor 1 Tahun 2016 tentang Kebiri Kimia angka 4 menyatakan "Dokter melanggar etik kedokteran masih seorang dokter dan menjadi tugas organisasi profesi untuk membinanya, tetapi bila dokter telah melanggar sumpah kedokteran maka dia tidak pantas lagi untuk menjalankan profesi mulia tersebut". Walaupun seakan-akan sumpah dan etik berdiri sendiri, ${ }^{20}$ namun dalam Pasal 1 KODEKI tahun 2012 dan penjelasannya, sumpah dokter menjadi kode etik sekaligus moral etik bagi setiap anggota IDI. ${ }^{21}$ Kode etik ini merupakan petunjuk moral setiap anggota IDI sekaligus sebagai penjamin mutu moral profesi dokter di mata masyarakat. Kepala Biro Hukum Pembinaan dan Pembelaan Anggota IDI Dr. HN. Nazar, Sp B., FINACS, MH. Kes., ${ }^{22}$ menyatakan dalam salah satu acara televisi swasta nasional: "...Dokter apabila dia melanggar etika dia tetap dokter....tugas organisasi, tugas profesinya, bina itu orang...tapi apabila dokter itu yang "trustnya" ada dari ujung rambut sampai ke ujung kakinya disitu masyarakat itu mempercayai terhadap "trust" itu, apabila dia langgar satu saja, dari dua puluh satu sumpahnya itu, dia tidak layak lagi, tidak layak lagi menjadi dokter".

Secara umum, sanksi administratif biasanya dikaitkan dengan konsekuensi dari suatu norma yang dirumuskan dalam bentuk larangan, perintah (keharusan) atau wajib (kewajiban). ${ }^{23}$ Berdasarkan penjelasan diatas rekomendasi pencabutan izin praktik yang diajukan MKEK IDI berproses sebagai berikut: ${ }^{24}$

1) Kepala Dinas Kesehatan Kabupaten/Kota Mencabut Surat Izin Praktik (SIP) dokter yang direkomendasikan dicabut SIP nya oleh organisasi profesinya.

2) Keputusan pencabutan Surat Izin Praktik (SIP) disampaikan kepada dokter yang direkomendasikan dicabut SIP nya dalam waktu paling lambat 14 hari kerja.

3) Dokter yang dicabut SIP nya dapat mengajukan keberatan kepada Kepala Dinas Kesehatan Provinsi apabila tidak dapat menerima keputusan pencabutan Surat Izin Praktik (SIP) tersebut selambatnya 14 (empat belas) hari setelah Keputusan diterima untuk diteruskan kepada Menteri Kesehatan; dan

4) Menteri meneruskannya kepada Majelis Kehormatan Disiplin Kedokteran Indonesia (MKDKI), selambatnya 14 (empat belas) hari setelah menerima surat keberatan dalam perkara pelanggaran disiplin kedokteran.

\footnotetext{
${ }^{18}$ Veronica Komalawati, "Kompetensi dan Kewenangan Praktik Kedokteran : Prespektif Hukum di Indonesia”, Jurnal Ilmiah Hukum De Jure, Vol 3 No. 1, (2018), hlm 152.

${ }^{19}$ Menimbang, huruf b. Undang-Undang Nomor 5 Tahun 2014 tentang Aparatur Sipil Negara.

${ }^{20}$ Ratna Winahayu Lestari Dewi, “Aborsi Bagi Korban Pemerkosaan Dalam Perspketif Etika Profesi Kedokteran, Hukum Islam dan Peraturan Perundang-Undangan”, Jurnal Perspektif, Vol 16 No. 2, (2011), hlm 79-80.

${ }^{21}$ Rieke Arya Putri, Rahmatina B. Herman, Yulistini, "Gambaran Penerapan Kode Etik Kedokteran Indonesai Pada Dokter Umum di Puskesmas di Kota Padang”, Jurnal Kesehatan Andalas, Vol 4 No.2, (2015), hlm 464-465.

${ }^{22}$ Dr.Nazar, Tegas!! IDI: Kode etik Dokter Itu Memberikan Pelayanan ILC (27/8/2019)..., https:/youtu.be/Jz94NTS_Sol, www.youtube.com.

${ }^{23}$ Wicipto Setiadi, "Sanksi Administratif Sebagai Salah Satu Instrumen Penegakan Hukum Dalam Peraturan PerundangUndangan", Jurnal Legislasi Indonesia, Vol 6 No. 4, (2009), hlm 606-607.

${ }^{24}$ Marjan Miharja, "Selain Administratif Terhadap Tindakan Mal Praktik Dokter dan Rumah Sakit di Indonesia", Jurnal Ilmu Hukum De Lega Lata, Vol 5 No.1, (2020), hlm 52-53.
} 
5) Kepala Dinas Kesehatan Kabupaten/Kota melaporkan setiap pencabutan SIP Dokter dan Dokter Gigi kepada Kepala Badan Pengembangan dan Pemberdayaan Sumber Daya Manusia Kesehatan Kementerian Kesehatan, Ketua KKI dan Kepala Dinas Kesehatan Provinsi, serta tembusannya disampaikan kepada organisasi profesi setempat. ${ }^{25}$

Selain itu, dokter yang bersangkutan dapat mengajukan upaya administratif berupa keberatan atau banding terhadap keputusan tata usaha negara berupa pencabutan SIP apabila merasa dirugikan. ${ }^{26}$ Hal lain yang dapat dilakukan adalah mengajukan gugatan tertulis kepada Pengadilan Tata Usaha Negara (PTUN) yang berwenang berisikan tuntutan agar Keputusan Tata Usaha Negara yang dirasa memberatkan itu dinyatakan batal atau tidak sah, dengan atau tanpa disertai tuntutan ganti rugi dan/atau rehabilitasi. ${ }^{27}$ Alur Pembinaan dan pengawasan Penyelenggaraan Praktik Kedokteran ${ }^{28}$ dan Upaya Administratif terhadap KTUN dapat digambarkan pada bagan dibawah ini:

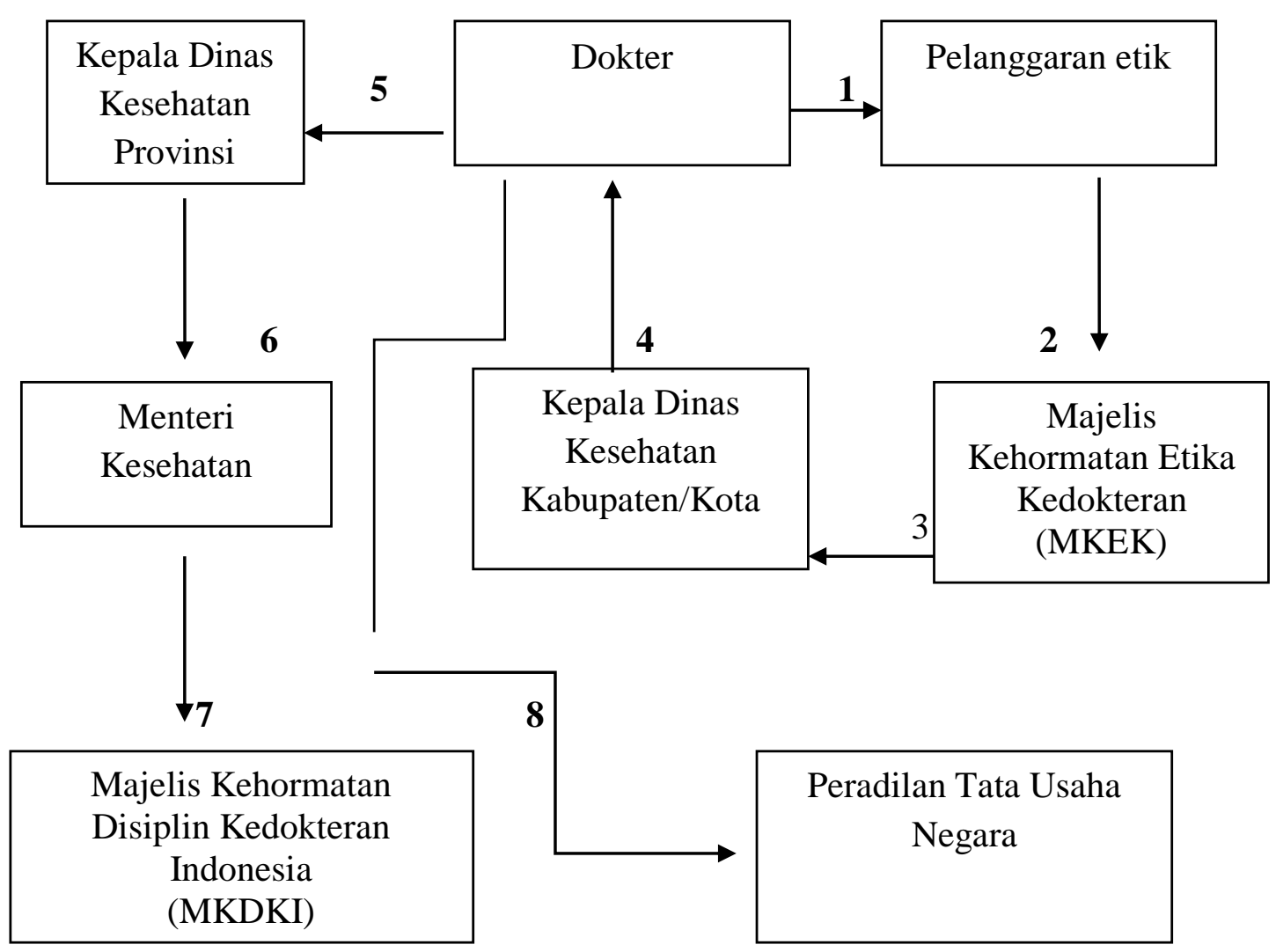

Secara teoritis sanksi administratif dapat berbentuk: a. Peringatan/teguran lisan; b. Peringatan/teguran tertulis; c. Tindakan paksa pemerintahan (bestuursdwang/politie dwang);

\footnotetext{
25 Pasal 32, Pasal 33 dan Pasal 34, Peraturan menteri kesehatan No.2052 Tahun 2011 tentang Izin Praktik dan Pelaksanaan Praktik Kedokteran

${ }^{26}$ Pasal 75 Undang-Undang Nomor 30 Tahun 2014 tentang Administrasi Pemerintahan.

${ }^{27}$ Pasal 53 Undang-Undang Nomor 5 Tahun 1986 tentang Peradilan Tata Usaha Negara

${ }^{28}$ Permenkes No. 2052 tahun 2011 tentang izin praktik dan pelaksanaan praktik kedokteran
} 
d. Penarikan kembali keputusan yang menguntungkan: e. Denda administratif; f. Pengenaan uang paksa (dwangsom). Sementara makna stipulatif dari sanksi administratif berupa Pemberhentian dari Jabatan adalah pemberhentian sehingga seorang PNS tidak dapat lagi menduduki Jabatan Administrasi, Jabatan Fungsional, atau Jabatan Pimpinan Tinggi. ${ }^{29}$ Dokter dapat diberhentikan dari Jabatan Fungsional apabila a. mengundurkan diri dari Jabatan; b. diberhentikan sementara sebagai PNS; c. menjalani cuti di luar tanggungan negara; $d$. menjalani tugas belajar lebih dari 6 (enam) bulan; e. ditugaskan secara penuh di luar Jabatan Fungsional; atau f. tidak memenuhi persyaratan Jabatan. ${ }^{30}$

Pasal 68 ayat (4) UU ASN mengatur PNS dapat dimutasi berdasarkan kualifikasi, kompetensi, dan penilaian kinerja antar dan antara Jabatan Pimpinan Tinggi, Jabatan Administrasi, dan Jabatan Fungsional di Instansi Pusat dan Instansi Daerah. Kemudian pada Pasal 77 ayat (6) PNS berdasarkan penilaian kinerja yang tidak mencapai target kinerja dapat dikenakan sanksi administrasi sampai dengan pemberhentian dengan tahapan sebagai berikut: Dokter ASN diberikan kesempatan selama 6 (enam) bulan untuk memperbaiki kinerjanya dan harus mengikuti uji kompetensi kembali bila tidak dapat memperbaiki kinerja. Kemudian dapat dilakukan mutasi ataupun demosi pada jabatan lain bila tidak memenuhi standar kompetensi jabatan. Dokter ASN ditempatkan sementara pada jabatan tertentu dalam waktu paling lama 1 (satu) tahun Bila tidak tersedia jabatan yang lowong kemudian diberhentikan dengan hormat setelah 1 (satu) tahun tidak tersedia lowongan jabatan sesuai dengan kompetensinya sebagai pejabat fungsional dokter. ${ }^{31}$

\section{Kesimpulan}

Hasil penelitian yang dilakukan menunjukkan kesimpulan yakni kehilangan wewenang formil karena sanksi etik berupa rekomendasi pencabutan Surat Izin Praktek, tidak berimplikasi terhadap jabatan fungsional dokter ASN kecuali proses hukum administrasinya menetapkan wewenang materiilnya juga dicabut. Lalu kebijakan pembinaan pejabat fungsional dokter ASN dalam hubungannya dengan pelanggaran kode etik dokter berupa:

a. Dokter yang mendapat sanksi harus melakukan uji kompetensi untuk dapat duduk kembali dalam jabatan.

b. Dipindahkan dalam jabatan lain yang sesuai dengan kompetensinya apabila tidak lulus uji kompetensi.

c. Ditempatkan dalam jabatan tertentu dalam waktu satu tahun, bila tidak tersedia lowongan.

d. Diberhentikan dengan hormat dokter ASN, bila tetap tidak tersedia lowongan yang sesuai dengan kompetensinya setelah satu tahun.

\section{Daftar Pustaka}

A. Buku

Marbun, S.F., Hukum Administrasi Negara I (Administrative Law I), Yogyakarta, FH UII, Cetakan Kedua, 2018.

B. Jurnal

Arief B. Sidharta, "Etika dan Kode Etik Profesi Hukum", Veritas et Justitia, Vol 1 No.1, 2015. DOI: https://doi.org/10.25123/vej.1423.

\footnotetext{
${ }^{29}$ Pasal 1 angka 21 PP nomor 11 tahun 2017.

${ }^{30}$ Pasal 94 ayat (1) PP nomor 11 tahun 2017.

${ }^{31}$ Pasal 58 PP Nomor 30 Tahun 2019 tentang penilaian kinerja PNS
} 
Dian Mauli, "Tanggung Jawab Hukum Dokter Terhadap Kesalahan Diagnosis Penyakit Kepada Pasien”, Jurnal Cepalo, Vol 2 No.1, 2018. DOI: https://doi.org/10.25041/cepalo.v2no1.1760.

Dr.Nazar, Tegas!! IDI: Kode etik Dokter Itu Memberikan Pelayanan ILC (27/8/2019), https:/youtu.be/Jz94NTS_Sol, www.youtube.com.

Fred Amein, dikutip Yussy A. Mannas, "Hubungan Hukum Dokter dan Pasien Serta Tanggung Jawab Dokter Dalam Penyelenggaraan Pelayanan Kesehatan”, Jurnal Cita Hukum, Vol 6 No.1, 2018. DOI: https://doi.org/10.15408/jch.v6i1.8274.

Idris, Mas'ud, Tanggung Jawab Dan Etika profesi Dokter Dalam Bidang Hukum, https://media.neliti.com/media/publications/12557-ID-tanggung-jawab-dan-etika-profesidokter-dalam-bidang-hukum.pdf, diakses tanggal 27 desember 2019.

Irfan, Januarita Dyah Pitaloka, Adif Rachmat Nugraha, "Rekrutmen ASN Tenaga Kesehatan Untuk Merespon Covid-19", The Indonesian Journal of Development Planning, Vol 4 No.2, (2020), https://doi.org/10.36574/jpp.v4i2.115.

Julius Pelafu, "Pelaksanaan Penegakan Kode Etik Kedokteran", Jurnal Lex Crimen, Vol 4 No. 3, 2015.

Lukman Hakim, "Kewenagan Organ Negara Dalam Penyelenggaraan Pemerintahan", Jurnal Konstitusi, Vol 4 No.1, 2011.

Marjan Miharja, "Selain Administratif Terhadap Tindakan Mal Praktik Dokter dan Rumah Sakit di Indonesia", Jurnal Ilmu Hukum De Lega Lata, Vol 5 No.1, 2020. https://doi.org/10.30596/dll.v5i1.3445.

Nelson Bastian Nope, "Mutasi Pejabat Fungsional ke Dalam Jabatan Struktural Di Era Otonomi $\begin{array}{llllll}\text { Daerah", } & \text { Jurnal } & \text { Yusticia, } & \text { Vol } & 4 & \text { No.2, }\end{array}$ DOI: https://doi.org/10.20961/yustisia.v4i2.8654.

Ratna Winahayu Lestari Dewi, “Aborsi Bagi Korban Pemerkosaan Dalam Perspketif Etika Profesi Kedokteran, Hukum Islam dan Peraturan Perundang-Undangan", Jurnal Perspektif, Vol 16 No. 2, 2011. DOI: http://dx.doi.org/10.30742/perspektif.v16i2.71.

Rieke Arya Putri, Rahmatina B. Herman, Yulistini, "Gambaran Penerapan Kode Etik Kedokteran Indonesai Pada Dokter Umum di Puskesmas di Kota Padang", Jurnal Kesehatan Andalas, Vol 4 No.2, 2015. DOI: https://doi.org/10.25077/jka.v4i2.274.

Setyo Trisnadi, "Perlindungan Hukum Profesi Dokter Dalam Penyelesaian Sengketa Medis", Jurnal Pembaharuan Hukum, Vol 4 No. 1, $2017 . \quad$ DOI: http://dx.doi.org/10.26532/jph.v4i1.1656.

Sidik Kahono, Muhammad Junaidi, A. Heru Nuswanto, “Tinjuan Yuridis Terhadap Ketentuan Asas Contrarius Actus Menurut Undang-Undang Nomor 16 Tahun 2017 tentang Penetapan Peraturan Pemerintah Pengganti Undang-Undang Nomor 2 Tahun 2017 tentang Perubahan Atas Undang-Undang Nomor 17 Tahun 2013 tentang Organisasi Kemasyakaratan, Jurnal Semarang Law Review, 2020.

Sukohar Asep, Novita Carolia, "Peran Majelis Kehormatan Etik Kedokteran Indonesia (MKEK) dalam Pencegahan dan Penyelesaian Malpraktek Kedokteran”, Jurnal Kedokteran Unila Vol (1) Nomor 2, 2016.

Suwardi Sagama, "Reformulasi Hierarki Peraturan Pada Pembentukan Peraturan PerundangUndangan di Indonesia", Jurnal Volksgeist, Vol 2 No. 2, 2018. DOI: 10.24090/VOLKSGEIST.V1I2.1967.

Veronica Komalawati, "Kompetensi dan Kewenangan Praktik Kedokteran: Prespektif Hukum di Indonesia", Jurnal Ilmiah Hukum De Jure, Vol 3 No. 1, 2018. DOI: http://dx.doi.org/10.35706/de'jure.v3i1.1891.

Wicipto Setiadi, "Sanksi Administratif Sebagai Salah Satu Instrumen Penegakan Hukum Dalam Peraturan Perundang-Undangan”, Jurnal Legislasi Indonesia, Vol 6 No. 4, 2009.

C. Undang-undang

Peraturan menteri kesehatan No.2052 Tahun 2011 tentang Izin Praktik dan Pelaksanaan Praktik Kedokteran.

Peraturan Pemerintah Nomor 30 Tahun 2019 tentang penilaian kinerja PNS. 
Undang-Undang Nomor 29 Tahun 2004 tentang Praktik Kedokteran.

Undang-Undang Nomor 30 Tahun 2014 tentang Administrasi Pemerintahan.

Undang-Undang Nomor 5 Tahun 1986 tentang Peradilan Tata Usaha Negara.

Undang-Undang Nomor 5 Tahun 2014 tentang Aparatur Sipil Negara.

D. Internet

Majalah Mahkamah Konstitusi, diakses pada selasa, 6 Januari 2019, pukul 10.37 WIB. 
